\title{
Intergenerational land conflict in northern Uganda: children, customary law and return migration
}

\author{
Sandra F. Joireman
}

The experience of forced migration has become common. Indeed, displacement as a result of conflict is now at the highest levels ever recorded (UNHCR 2015: 33). But what happens when the conflict that drove people from their homes is over? Those who return to their communities after conflict find them changed. Children who grow up in refugee camps or other places of refuge bring different perspectives on life and livelihoods than those of parents who knew peace and a well-functioning community. This article focuses on a single instance of forced migration, or, more correctly, on a collection of experiences of displacement surrounding one conflict - between the Lord's Resistance Army (LRA) and the government of Uganda in northern Uganda. It examines the property conflicts that developed as people returned from the camps and re-established life in their home communities, focusing on the intergenerational nature of those conflicts in the context of a developing land market. The findings from this work are instructive in understanding post-conflict community reconstruction challenges in other settings in sub-Saharan Africa where customary law applies, such as northern Nigeria, South Sudan, and the eastern part of the Democratic Republic of Congo.

In northern Uganda, the different expectations and actions of children who came of age during and immediately after the conflict highlight social change resulting from violence and displacement. Emphasis here is given to how the definition and social place of 'children' under customary law can contribute to land conflicts and how the interests of a younger generation come into conflict with tradition and patterns of customary land allocation. In northern Uganda, the regional experience of return migration coincided with government efforts to formalize customary landholding, accelerating change in the tenure system. There are three contributions to existing literature in this article, beginning with a discussion of children's property rights under customary and statute law in Uganda. The second contribution is the identification of the dual nature of children during complex emergencies as both victims and agents. Finally, the article contributes to the existing knowledge on post-conflict return and the economic and political context of community reconstruction in northern Uganda.

Narratives relating to children in conflict highlight their vulnerability. Children are exposed to violence, exploitation, disease and malnutrition during periods of conflict. Their future livelihoods are also threatened should they lose their ties to family and their communities of origin. In conflicts, children can become perpetrators of violence if they are recruited or compelled into combat. Yet, although

\footnotetext{
Sandra F. Joireman is the Weinstein Chair of International Studies and a professor of political science at the University of Richmond. Her work covers topics related to property rights, legal development and post-conflict return migration and has recently been published in International Migration, Development and Change and Political Geography. Email: sjoirema@richmond.edu 
violence threatens their security, children can also adapt to conflict in unanticipated ways (Boyden 2003). They can be agents of change in post-conflict settings as they take advantage of social upheaval to assert rights and preferences previously foreclosed by the constraints of custom and tradition (Hampshire et al. 2008). With regard to property rights, children can be both disenfranchised by violent conflict and vectors of institutional change.

I begin by discussing the nature of children's property under Ugandan law, both customary and public. In the second section, the specific ways in which conflict and displacement threaten children's property rights are identified. The third section of the article addresses the impact that the conflict in northern Uganda has had on the property rights of children and the role that young adults who came of age during and after the conflict have played within the customary tenure system. The article concludes with an examination of conflict resolution forums and contested authority structures. Evidence comes from several sources, the most important of which are interviews conducted in Gulu and Kampala in May and June 2015. The interviews were conducted in English, or in Acholi with translation, transcribed, and coded for content. Approximately twenty of the interview subjects were involved in land administration and dispute resolution, either at a formal level or through traditional mechanisms and NGOs. ${ }^{1}$ The goal of the interviews was to identify the nature of disputes involving young adults and specific issues that arose surrounding their property rights. The interviews build on more than a decade of previous research on Ugandan property rights and legal change. Field research was augmented by secondary sources, particularly survey research conducted in northern Uganda after the conflict, which adds a helpful interpretive layer to the interview data.

\section{Children and Ugandan law}

The 1995 Ugandan Constitution, its fourth, was the result of an extensive consultative process. While it is progressive in recognizing the special needs of children - and of orphans in particular - it raised uncertainties regarding the property rights of those holding their lands on a customary basis. Farmers with customary landholdings were guaranteed security of tenure by Article 237, but it was also stated that 'land under customary tenure may be converted to freehold land ownership by registration'. While this was in keeping with progressive theories of property, the mechanisms for registering and converting land were not in place, nor were they articulated in the Constitution; they were developed later in the Land Act of 1998.

\footnotetext{
${ }^{1}$ There was one notable gap in the interviews, as I did not meet with anyone from the magistrate's court during the time I was in Gulu. The court was going through a major shake-up after the magistrate had been dismissed for bribery. As with all interview research, and consistent with my Institutional Review Board guidelines, I followed a strict protocol for informed consent with each of my interview subjects. A large percentage of people wanted to be interviewed on the record with full attribution. Indeed, one of my subjects asked to see my notes so that he could check to make sure that his name was spelled correctly. Another subject insisted that I take his email address for follow-up questions. I am deeply grateful to those interviewed for their time and their openness.
} 
The Land Act brought about a transformation of the titling and dispute resolution systems and basic land law in Uganda. It created a mechanism for customary land to be formally recognized and then titled through certificates of customary ownership. The law captured contemporary economic thinking regarding property rights, in that there was a clear focus on creating security of customary tenure and titled freehold where it had not existed previously (Joireman 2007). The Land Act provided a legal path for transitioning from customary tenure to titled freehold. Mechanisms of land administration were decentralized to newly created district land boards and area land committees. Dispute resolution over land issues was to happen through land tribunals at the district level and through the Local Council (LC) Courts:

Local Council Courts - appointed from among the members of the Local Councils serve as the first instance to adjudicate land disputes. This LC-structure was expected to provide space for 'customary' authorities and their ways of administering and (collectively) managing land and dealing with land disputes. (van Leeuwen 2014: 295)

The intention of these legal changes was to make land administration and conflict adjudication accessible to citizens.

The 1998 Land Act also recognized children as holding an interest in customary land and prevented the transfer of family land without the approval of a land committee in order to protect the future rights of children. The same law also recognized the inheritance rights of customary land for orphaned minors. ${ }^{2}$ In Uganda, the state has led efforts to address children's property rights in customary systems. In this case, the goal was to protect children's property from those who might take advantage of their vulnerability. One person described the problem with regard to orphaned minors as follows:

The relatives are often eager to take the land. During the funeral they will divide the land and they will say that they are taking care of the children, but that might mean that the one who should have inherited the land will end up as a house boy or a house girl in the home of the relatives. ${ }^{3}$

Yet, attempts to provide legal recognition of children's property rights under statute law proved to be unworkable as they undermined the alienability of the land and therefore its use as collateral for loans, which was one of the goals of the Land Act. ${ }^{4}$ The 2004 Amendments to the Land Act revoked recognized property rights for minors. ${ }^{5}$

Uganda finalized a National Land Policy in February 2013, partly to clarify some of the issues left outstanding after the Constitution and Land Act. The land policy clarified the decentralization of land administration and the recognition of customary tenure. Land tribunals, which had ceased to function in the few places where they had been operative, were to be revived. The land policy restated

\footnotetext{
${ }^{2}$ Ugandan Land Act, Chapter 227, 39 (1) iii and iv.

${ }^{3}$ Interview with Carol Bunga Idembe, Uganda Women's Network, Kampala, 12 September 2005.

${ }^{4}$ Personal communication with Patrick McAuslan, London, July 2005.

${ }^{5}$ Land (Amendment) Act 2004, Section 20.
} 
that customary land held individually should be convertible to freehold tenure (Ministry of Lands 2013: 17). It also called for further legislation to protect the land rights of children (ibid.: 24). The 1995 Constitution, 1998 Land Act and 2013 National Land Policy all recognize customary tenure. The Land Act and land policy also acknowledge the role of customary leaders in resolving disputes. The land system in place is dual (customary and formal land rights) and convertible from customary to statutory, but not the other way. There is no recognition in Ugandan statute law or in the National Land Policy, of the unique challenges faced by northern Uganda as a post-conflict area. However, the policies noted above set the legal framework within which land issues arise.

\section{Children and customary law}

Customary law is a body of rules governing personal status, communal resources and local organization. In many parts of sub-Saharan Africa, including northern Uganda, customary law controls access to resources such as land, trees and water, and sometimes labour; it is extremely diverse and dependent on local context (Deng 2011; Hinz 2010; Toulmin et al. 2002; Woodman 2008). ${ }^{6}$ Addressing customary law in sub-Saharan Africa, Gordon Woodman notes: 'A customary law may be defined as a normative order observed by a population, having been formed by regular social behavior and the development of an accompanying sense of obligation' (2011: 10). Unlike common and civil law, customary law is rarely ascertained or written down. In Uganda, there are nascent efforts to ascertain customary law (Ker Kwaro Acholi 2008; Kumam Elders' Forum 2011); however, to date these have been fairly basic exercises that often leave out key elements. It is unclear whether these written documents provide their respective communities with guidance.

As members of a lineage or clan, children have a claim to nurture and protection as well as to the resources at the disposal of the group. For children, customary rights to property are distinctly different from those under statute law, as they are not automatically assumed when a child reaches his or her legal majority or on the death of a parent, but are contingent on marriage, the availability of land, and community standing.

In many, if not most, customary tenure systems in Uganda, a male member of a clan or lineage receives his own land at marriage. ${ }^{7}$ Prior to marriage, young men are regarded as youth and not entitled to possess land. A discussion on a Ugandan land registration case illustrates both the legal principle and the recognition of customary practice in statutory law.

The incapacity of children or sons to own land was articulately stated in Bundanga v. Kagumeho (Civil Appeal No. 117/67). The magistrate said that, under the relevant customary law a son could not sue his father for the land which belongs to the father. $\mathrm{He}$

\footnotetext{
${ }^{6}$ This was also articulated in an interview with Teresa Eilu, Programme Manager, Law and Equality Movement Uganda, Kampala, 1 June 2015.

${ }^{7}$ For comparison, see recent research on the intersection between land rights and marriage in Tanzania, as discussed in Dancer (2015). The exclusive gender use here is deliberate, as male claims to customary land are uncontested while female claims are unusual, progressive and happening in some areas but not in others.
} 
could not even sue the father in respect of a piece of land which the son himself purchased. Under customary law, anything done by a young person (infants) is the property of the parents until the parents decide to hand it over to the son after marriage. Until this is done the trees and the land belong to the parents. The use of the word 'Parent' has a strong social overtone. In the social sense one may loosely say that the land belongs to the parents. But in the strict legal sense, ownership is only vested in the man. Therefore, generally, unmarried male infants and women cannot own land. They merely have the right to use the land. (Obol-Ochola 1973: 136)

Achieving majority does not always mean gaining access to property under customary law. Typically, land for a home and cultivation would come at the time it was needed to set up an independent household: that is, after marriage, at which point adulthood is established. ${ }^{8}$

Children may have stronger potential or future rights to land than wives or mothers under customary law because children are part of the lineage while women marrying into the family are not (Hakansson 1994). Customary law in Uganda rarely accords women autonomous rights to immovable property such as land and houses, although this is beginning to change (Joireman 2008). In Uganda, women have use rights to land. While use rights are defended by customary adjudicatory mechanisms, they are not as strong as the land claims of children who are part of the lineage by blood. ${ }^{9}$ Of course, women can always purchase land in their own names, which they would then fully control and be able to dispose of in any way they chose. Children, however, have a direct claim to lineage resources, and therefore their rights are stronger, particularly if they are male children. Increasingly, there is a shift to invest female children with rights to land and resources from their natal lineage. ${ }^{10}$

\footnotetext{
${ }^{8}$ In this regard, customary law differs significantly from both common and civil law. Interestingly, although this statement applies well to the contemporary setting in and around Gulu, it differs from what was observed by colonial anthropologist Frank Girling in his study of the Acholi. Girling noted that young men would often farm on their father's land, establishing their own household there and working with their father until he became too old to farm, at which point they would take over. However, Girling also noted the prevalence of primogeniture, which is not currently practised:

On the death of the father, the eldest son inherits his property. Ming calo latin kayo, as stupid as an eldest son, says the Acholi proverb, recognizing the fact that by his birth-right the eldest son has little occasion to exert himself to obtain a wife, and so has less need for astuteness than the others. The eldest son holds the property in trust, however, for his younger brothers and is morally bound to provide for them; but it is unlikely that this obligation was ever honoured completely. (Girling 1960: 33)

For information on precolonial practices and the importance of marriage, see Owot (1976).

${ }^{9}$ One informant stated: 'It was of pride and great value for women to be married and go and establish a new home with her husband. Divorce was rare. In many cases a married woman would actually take over responsibilities of the family she was married in and she would not think to come back to her father's home except for brief occasional visits. In that case she was more permanent at her husband's home than at her father's. In view of this, her father's side would not think of giving her [a] portion of her father's land. In case she divorced, the brother who used her bride price to marry a wife was culturally obligated to accept her back home and take care of her and her children' (personal communication with Kilara Oruni, 4 May 2016).

${ }^{10}$ This is noted in the recently ascertained customary law for the Acholi and Kumam, a related ethnic group (Ker Kwaro Acholi 2008; Kumam Elders' Forum 2011).
} 
Conflict has a specific and discernible impact on children's property rights under customary law as a result of two interrelated issues: the potential lack of guardianship and displacement from the home area. Generally, any circumstance that robs children of a parent or a guardian, whether it be through death or displacement, challenges the ability of a child to claim their property rights. The malleability of customary tenure systems and the lack of a formal record of lineage membership and landholdings exacerbate this problem in customary settings. Writing about Southern and Eastern Africa in the early 2000s at the height of the AIDS pandemic, Scott Drimie noted that orphaned children were at risk of losing both the presently held property of the parents as well as future access rights to lineage land. He observed:

A major contributor to this threat is the lack of direct land rights for children. As minors they cannot be signatories or custodians of property. Their parents are their security, and with their demise, insecurity overshadows their entire existence. This situation affected orphans whose parents lived on ancestral land, and had no title deeds in their names at the time of their deaths. Although there are laws protecting property for minors, they depend on the next of kin ensuring that the orphans' property is declared to the local administration. If this does not happen, orphans have to wait until they come of age and have the resources to fight for their rights in court. (Drimie 2002: 15)

It is challenging for children to assert their right to customary land when they have no well-intentioned guardian. This finding is echoed by Laurel Rose, who noted evidence from Rwanda of land-grabbers taking children's customary land, selling it, and appropriating the proceeds (2005). Interviews in Uganda during the AIDS crisis documented the struggle of Family Protection Officers to ensure that orphans were provided for by their extended families who were reluctant to do so. ${ }^{11}$ In all of these crises, there was insufficient protection of children's customary land rights, a salient threat where farming is the principal form of livelihood.

Customary land tenure systems are dependent on the role and knowledge of customary leaders. When people are displaced, those leaders can change and/or die, and the knowledge they carried with them disappears. When a community is torn by conflict, leadership change and population displacement, the possibility for adult exploitation of the property rights of minors is magnified (Joireman 2014). The self-interested behaviour of an older family member can block the land claims of the next generation, because the displacement occurred when they were minors, when their property rights to customary land were still future rights. In northern Uganda, there were instances of older relatives taking advantage of children orphaned in the camps to subvert their land rights. These actions were considered aberrant and condemned as illegitimate by those familiar with the customary system and with the obligations of the clan to ensure the well-being of its children. ${ }^{12}$ Without altruistic guardians, children have difficulty accessing land in customary systems where there is no legally registered title or certification. With

\footnotetext{
${ }^{11}$ Interview, Mbarara, 3 February 2006.

${ }^{12}$ Interviews with Susan Mildred Aber, Senior Land Management Officer, Amuru District Local Government, Gulu, 26 May 2015; Patrick Ong'ara and Zakeo Lubeja, Chief and Subchief, Gulu, 27 May 2015.
} 
no legal records regarding land claims, the restoration of property rights is dependent on the recollection of family members, recognition by authority figures, and return to the community.

\section{Intergenerational conflict and customary law}

The narrative on children's property rights set out above accurately suggests a vulnerability to resource loss that attends displacement or the death of a guardian. Yet, this is only one part of a complex narrative of intergenerational change and resource access. Violent conflict changes the nature of societies. It shifts interests, incentives and loyalties in unpredictable ways. In a few notable instances in other parts of sub-Saharan Africa, youth have used conflict and the resulting disintegration of the social ties of customary law as an opportunity to reconstruct a customary tenure system that benefits themselves. We see evidence of this happening in Côte d'Ivoire, where the conclusion of the civil war led to the re-establishment of communities, some under the leadership of self-declared 'customary leaders' who were really no more than groups of young, former combatants attempting to control resources in a way that would grant them better land (McCallin and Montemurro 2009). Similarly, in Liberia, ex-combatants took land for themselves without waiting for the permission of elders or traditional leaders. 'When the war ended, these young fighters used their physical presence and position as victorious, and capacity to rapidly organize in self-defence groups if necessary, to appropriate land' (Rincon 2010: 16). Post-conflict situations present a disruption to the social order, a moment when the path-dependent institutions of authority and resource access can be altered or changed by powerful actors. In the cases noted above, youth would not have been able to control resource access under the previously functioning systems of customary law, but the fact that they were armed and the customary systems had not yet been re-established created a moment in which they could redefine the rules of the game and assert control over land.

\section{Northern Uganda}

The conflict between the government and the LRA was one in which civilians were both victims of collateral violence and specific targets. The LRA gained notoriety for its extraordinarily malevolent practice of abducting children to serve as soldiers, servants and sex slaves. In addition to direct violence, local populations suffered from the trauma of displacement, and with it the burden of disease and the lack of food and shelter. By 2005, approximately 1.8 million people, including 1.2 million Acholi (90 per cent), were displaced by the conflict (Pham et al. 2005). There were two main causes of internal displacement: first, people spontaneously fled violence as it began to affect their communities, moving to towns and trading centres close to their homes or outside Acholi, swelling the urban population. Second, beginning in 1996, the government enacted a policy to move people into camps, ostensibly for their own protection and to ensure that they did not 
provide support to the LRA (Roberts et al. 2008). ${ }^{13}$ Indeed, the government forcibly displaced civilians, telling people in some areas that if they did not move to the camps, they would be considered rebels and killed (Branch 2011: 76).

The statistic of 1.8 million displaced people encompassed only those who resided in IDP (internally displaced persons) camps and were officially counted, not those who moved to major cities and trading centres for safety. Life in the camps was horrific and did not protect people from the LRA. At the height of forced displacement in 2005, the World Health Organization reported 1,000 excess deaths per week in the camps (Uganda Ministry of Health and World Health Organization 2005). Poor protection and miserable camp conditions inflicted damage on social relationships. Exposure to violence fostered a generation disconnected from traditional norms of living, as roles and expectations shifted dramatically when people were removed from their normal livelihoods and contexts (Dolan 2009; Nannyonjo 2005; Vorhölter 2014). While people were displaced for the longest periods of time in Gulu (as long as two decades), a 2006 survey of approximately 900 households in neighbouring Pader and Lira found that the average length of displacement there was four years and four months (Adelman and Peterman 2014: 587).

Although no formal agreement has been concluded, a tentative peace has existed in northern Uganda since 2006. The LRA remains active, if severely weakened, in neighbouring countries, where they have been pursued by the Ugandan People's Defence Force as well as by US forces. From 2006, people began returning to their communities. Encouraged, sometimes pressured, by the government to return home, the vast majority had left the camps by the end of 2010 .

When people returned, there was a host of anecdotal accounts of conflicts as new actors laid claim to resources; communities engaged in struggles over the boundaries of collective landholdings; and some reports indicated that those who returned first to an area claimed the best land, rather than that which they had previously occupied (Onegi 2012). ${ }^{14}$ Ronald Atkinson has noted that: 'Numerous concerns have arisen about regaining access to such land after many years of forced displacement, including the death of many knowledgeable elders during those long years of war, and the unprecedented number of widows and orphans produced by the conflict' (2010: 333). It became apparent upon return that the contours of the land conflicts were often intergenerational in nature. Below, I identify four specific types of intergenerational land issues.

The first and most obvious issue was that children orphaned in the camps did not know their land or its boundaries. One of the problems in the reconstruction of communities in northern Uganda has been that the traditional leaders were displaced for so long that there was no longer local knowledge of land claims. 'As people return to their villages, they are confronted with the realization that over a period of 20 years, clan leaders, heads of households and the elderly who would have knowledge of the previous set-up in the villages are no

\footnotetext{
13،A catastrophe ignored', Economist, 22 July 2004.

${ }^{14}$ See also 'Uganda: escalating land disputes in the north', IRIN, 17 February 2011. There is evidence to suggest that not everyone returned to the original location of their homes and land (Joireman et al. 2012). Interview evidence also suggests that people were aware that land claims were not justified by previous occupation.
} 
more. ${ }^{15}$ Older relatives, particularly uncles, could assist with this problem if they chose to do so, but not all did. The absence of a guardian with knowledge of the rightful claims of young people and willing to defend their interests, combined with the death of some customary leaders in the camps, caused difficulty for orphans in accessing lineage land to farm. ${ }^{16}$ One chief noted that this was personally his experience; he could not properly remember the land boundaries and no longer had a parent to assist him. ${ }^{17}$

The second issue was that of young people claiming customary land only to sell it rather than use it for farming. ${ }^{18}$ While land sales are not unheard of in this area, nor is it just young people who sell land, historically sales have been rare. Some view sales as undesirable because selling land effectively moves it out of the customary system, thereby reducing the amount of land available to future generations. ${ }^{19}$ As noted above, while both customary and formal land rights are recognized in Ugandan land law, movement between the two is unidirectional towards formalization and out of the customary system. Blame was consistently placed on young people for claiming clan land - to which they have a right if their fathers belong to the lineage - and then selling that land. Their actions were seen as reprehensible because they were not using the land for its intended purpose of providing themselves with a livelihood while keeping the land under the control of the clan for future generations. Adults also sell customary land, but this was not consistently noted as a problem.

The third intergenerational land issue is gender-related. Under customary tenure systems in northern Uganda, women have secondary rights to land use and men have primary claims as members of the clan or lineage. Unmarried women can obtain land to farm from their natal clan, but women who have children are in a different category as the presence of a child makes it more difficult for them to claim land from their family. The clan of the child's father is supposed to provide the child's mother with land so that she can raise the children of his family on his clan land. There have been many cases in which young mothers have returned from captivity with the LRA or from the camps and their natal clan is not willing to give them land because under customary law they should receive land from the clan of the father of their child. ${ }^{20}$ Their children are pejoratively called 'bush children'. In a 2015 study of children born of war (CBW), the Justice and Reconciliation Project (JRP) reported on a consultation they conducted with 447 people in northern Uganda, including 380 members of the Women's Advocacy Network (WAN). Women involved in WAN reported caring for 1,609 children, of whom 493 (31 per cent) were CBW, with the

\footnotetext{
${ }^{15}$ 'Uganda: escalating land disputes in the north', IRIN, 17 February 2011.

${ }^{16}$ Interview with NGO official, Gulu, 25 May 2015.

${ }^{17}$ Interview with Patrick Ong'ara and Zakeo Lubeja, Chief and Sub-chief, Gulu, 27 May 2015.

${ }^{18}$ Interviews with NGO official, Gulu, 25 May 2015; LC5 official, Gulu, 25 May 2015; Simon Ogenwrot, Legal Officer, Centre for Reparation and Rehabilitation, Gulu, 28 May 2015; Sabiti Omara, Head of Land Rights Information Centre, Amuru, Uganda Land Alliance, Gulu, 25 May 2015.

${ }^{19}$ Koro Elders' Focus Group, Gulu, 27 May 2015.

${ }^{20}$ Interviews with Amos Canwat, former land committee chairman, Gulu, 27 May 2015; NGO official, Gulu, 25 May 2015; Koro Elders' Focus Group, Gulu, 27 May 2015; Simon Ogenwrot, Legal Officer, Centre for Reparation and Rehabilitation, Gulu, 28 May 2015; Sabiti Omara, Head of Land Rights Information Centre, Amuru, Uganda Land Alliance, Gulu, 25 May 2015.
} 
overwhelming majority of these children conceived as a result of sexual violence while the women were held in captivity (Opiyo 2015: 3). When children are born as a result of sexual violence, the mothers often do not know the identity of the father. When the father is unknown, women face a double challenge: (1) they are unable to make a land claim for the child; and (2) they face difficulty in getting land themselves from their natal clan. ${ }^{21}$ Women surveyed by the JRP were asked about their concerns for the future and 51 per cent of them identified land access for their children (Opiyo 2015: 6). The JRP is involved in trying to identify the fathers of these 'bush children' so that they will be able to make land claims. ${ }^{22}$ It is certainly not the case that all women who have CBW are excluded from their family land claims. Some natal families have accommodated the women - as they would have done in the past when land was abundant - but this is becoming less likely to happen because of the rising value of land, which makes clan elders more reluctant to give it to someone without a strong claim. ${ }^{23}$ Whyte et al. label this phenomenon as a kind of 'patrilineal fundamentalism', noting that 'Acholi tradition is invoked to exclude people who, by all accounts, were traditionally made welcome' (2012: 295). Acholi land allocation institutions are changing in response to rising land values, as economic theory would suggest (North 1990).

Youth are widely perceived to be the cause of land disputes and are often the perpetrators of violence if conflicts escalate. ${ }^{24}$ Koro elders report instances of youth threatening their older relatives, to force them to give the youth land that they can then sell. ${ }^{25}$ Others report children encouraging their parents to engage in conflicts over land. ${ }^{26}$ One respondent noted:

The elders are dependent on the youth and are afraid that if they insist on the right path that they will get no support from their children. The youth say, 'The grandfathers gave you land, but our grandfathers did not consult us. ${ }^{27}$

The narratives people use to describe the role of the youth in claiming and selling land, and thereby expressing agency, describe it as a violation of the traditional ways; they claim that ties of obligation between generations were stronger in the past when young men needed their fathers in order to pay bride price when they got married. Julia Vorhölter identified this as a familiar discourse after conflict: 'According to common belief, due to fundamental changes in socialization practices the young generation never learned societal rules and norms and therefore no longer knows Acholi culture' (Vorhölter 2014: 155). Traditionally, fathers gave the money for bride price and provided the land for a new household to farm. Indeed, Frank

\footnotetext{
${ }^{21}$ Koro Elders' Focus Group, Gulu, 27 May 2015; interview with NGO official, Gulu, 25 May 2015.

${ }^{22}$ Interview with Julian Hopwood, independent land consultant, Gulu, 26 May 2015.

${ }^{23}$ Interview with Simon Ogenwrot, Legal Officer, Centre for Reparation and Rehabilitation, Gulu, 28 May 2015.

${ }^{24}$ Interview with Sabiti Omara, Head of Land Rights Information Centre, Amuru, Uganda Land Alliance, Gulu, 25 May 2015.

${ }^{25}$ Koro Elders' Focus Group, Gulu, 27 May 2015.

${ }^{26}$ Interview with LC5 official, Gulu, 25 May 2015.

${ }^{27}$ Interview with Simon Ogenwrot, Legal Officer, Centre for Reparation and Rehabilitation, Gulu, 28 May 2015.
} 
Girling, in his study of the Acholi, noted the importance of both the consent of the father and his provision of bride price for sons to marry. In the absence of the father, this obligation falls to the agnatic kin. Men who were brought up in the homes of their mothers were to be pitied, as there would be no one to pay their bride price (Girling 1960: 70). ${ }^{28}$ When people were living in the camps, fathers were unable to pay bride price and lost a key mechanism through which they were able to exert control over sons (Vorhölter 2014). ${ }^{29}$

Lastly, many people raised the issue of the increasing population and the fact that more young people have a claim to customary land than in previous generations. ${ }^{30}$ The population of northern Uganda increased significantly during the period of displacement, well above the rest of Uganda. In northern Uganda, the overall growth rate from 1991 to 2002 was 4.6 per cent, compared with 3.2 per cent for Uganda as a whole (Uganda Bureau of Statistics 2009). Half the population is under the age of fifteen (Hopwood and Atkinson 2013: 18). Thus, the feeling that there are more young people to accommodate is accurate and problematic. It may also explain the perception that the land sale issue is a problem that originates with the youth rather than a generalized problem. A growing population makes intergenerational conflict more obvious and increases demand on customary land, and therefore its value.

These intergenerational issues are inconsistent across northern Uganda, with the customary systems working well in terms of land distribution and allocation in some places and poorly in others. For example, a number of people interviewed reported that there were more problems around land and intergenerational land conflicts in Amuru than in Gulu. ${ }^{31}$ This is not surprising as there was wide differentiation between areas of northern Uganda in terms of the distribution of violence during the conflict, the percentage of the population displaced, and the length of displacement. We should not expect consistency in the aftermath of a conflict that was experienced unevenly. Beyond variances in displacement and violence, additional explanations for differences in land conflicts might be found in the effectiveness of customary conflict resolution mechanisms and variables that influence the value of land, such as soil fertility and population density.

Violent conflict and displacement in northern Uganda have accelerated the commercialization of land. Government policy envisions a gradual transition from customary to formalized landholding and provides a mechanism through which this can happen. Yet, government land policy has not been sensitive to the unique aspects of post-conflict return migration in Acholi. It is clear that the land conflicts in northern Uganda are not exclusively about the mechanisms of making the customary system work well, but include the negotiation of a transition to a land market.

In other post-conflict settings in Uganda we see a similar pattern of displacement, resettlement and then privatization of land via sales of plots held under customary

\footnotetext{
${ }^{28}$ This problem persists today, with men brought up by their mother's family unable to pay bride price.

${ }^{29}$ Also interview with Ambrose Olaa, Acting Prime Minister, Ker Kwaro Acholi, Gulu, 29 May 2015.

${ }^{30}$ Interview with Patrick Ong'ara and Zakeo Lubeja, Chief and Sub-chief, Gulu, 27 May 2015; Koro Elders' Focus Group, Gulu, 27 May 2015.

${ }^{31}$ Interviews with NGO official, Gulu, 25 May 2015; LC5 official, Gulu, 25 May 2015; Fr. Joseph Okumu, Executive Director BOSCO Uganda, Gulu, 29 May 2015.
} 
tenure (Kandel 2016). Youth are embracing the changing options created by the Land Act and National Land Policy. The consequences of youth agency in selling land include the increasing speed of the transition from customary to formal landholding.

\section{Forums to shop}

A fascinating aspect of land conflicts in northern Uganda is the way in which the mediation of land disputes has become a means to make authority claims in the region. Many groups and individuals see the benefits of being perceived as trusted mediators of land conflicts. Control over land defines power in a place where the government presence is thin. LC1 officials in northern Uganda, the lowest level of elected representatives in Uganda, have not been replaced in over fifteen years because of a lack of funding for elections. ${ }^{32}$ Moreover, the full implementation of the 1998 Land Act has not occurred. Land governance bodies at parish, sub-county and district levels are lacking (Hopwood and Atkinson 2013: 9). Land tribunals, which were required by the 1998 Land Act, are also not operating: they were eliminated in 2010 in the few places in which they did exist because of a lack of funding. In spite of a renewed government commitment to land tribunals in the 2013 National Land Policy, they were still not present in Acholi at the time of writing this article. The absence of these institutions, and the questionable authority of existing LC1 officials, has led to an ambiguous institutional environment that enables a diversity of rule interpretations. It has also posed challenges to the resolution of conflicts over land. LC1 courts have limited legal purview over land matters. After serving for some time as a court of first instance, the Ministry of Justice and Constitutional Affairs stated that 'land issues should no longer be dealt with by LC1 and LC2 Courts but should directly proceed to Magistrate Courts' (van Leeuwen 2014: 297). Interviews suggested that this directive was being followed, and although LC courts might become involved in land disputes, they could only mediate rather than make an authoritative decision. ${ }^{33}$

Without functioning land tribunals, the court of first instance for land disputes is the magistrate's court, which is unaffordable and inaccessible for most people with disputes over customary land. ${ }^{34}$ Moreover, land disputes that do come before the magistrate are often kicked out of court and the plaintiffs are told to go back to the clan and resolve the problem there. ${ }^{35}$ A person could try to take a land dispute to the LC1 courts, and some do, but any decision made there would not hold up to challenges. Another option would be to pursue customary

\footnotetext{
${ }^{32}$ New elections for LC1 officials were scheduled to occur in March 2016, but were postponed because of a lack of funds.

${ }^{33}$ Interviews with Simon Ogenwrot, Legal Officer, Centre for Reparation and Rehabilitation, Gulu, 28 May 2015; Sabiti Omara, Head of Land Rights Information Centre, Amuru, Uganda Land Alliance, Gulu, 25 May 2015.

${ }^{34}$ For example, it is important to be represented by a lawyer at a magistrate's court.

${ }^{35}$ Interview with NGO official, Gulu, 25 May 2015. A similar problem has been found in other parts of Uganda when women try to bring land disputes to court only to have them sent back to be resolved through ADR by NGOs that target women's property rights (Joireman 2011: 81-101).
} 
sources of dispute resolution, and here again there are two options. One could pursue a complaint with clan leaders responsible for land governance; this is an extremely effective route to take for boundary disputes and minor land issues. In Acholi, there is also the option of going through the traditional institution, the Ker Kwaro Acholi. ${ }^{36}$ However, the Ker Kwaro is not widely respected, nor would its decision be final or enforceable. In addition to the government and customary conflict resolution routes there are further alternatives. NGOs and religious leaders have been active in resolving land disputes in northern Uganda through alternative dispute resolution (ADR). ${ }^{37}$ Groups such as the Uganda Land Alliance, the Acholi Religious Leaders Peace Initiative, the Justice and Reconciliation Project and the Centre for Reparation and Rehabilitation assist people with land disputes through legal education and mediation.

This is a wide array of conflict resolution forums. What we see represented in these forums are different sources of political power in Acholi: the local customary leaders, the government-recognized customary leaders, local government representatives, legal authorities, religious leaders and NGOs. All want their authority to be recognized. Clan leaders and those from the traditional institutions would like the customary tenure system to be strengthened and their own roles to grow. Calls upon them to mediate land conflicts justify their claims to a broader societal role. Similarly, NGOs or religious leaders engaged in resolving land disputes through ADR can also claim success in their mission and an important role in the local community should they be called upon to mediate land disputes. In this post-war context in which the government institutions are under-resourced and not fully functional, mediation of land disputes legitimizes claims of authority, and anyone choosing one of these forums, whatever their age, increases the power of that institution.

\section{Conclusion}

Forced migration creates specific threats to children's property rights, increasing the possibility that they will lose access to land that they would otherwise be entitled to under customary law. When children become separated from parents or guardians and displaced from their homes, they can lose critical knowledge regarding the nature and extent of future land claims. In northern Uganda, where community leaders and clan elders were also displaced, a lack of information impeding young people's land claims was one of the intergenerational land problems that appeared when people returned after the conflict.

Customary law in northern Uganda recognizes a child's land rights as coming through the paternal family line, although there are some instances in which land from the mother's family might also be claimed. This has posed a unique problem for young women who have had children during the conflict, as these women do

\footnotetext{
${ }^{36}$ The Ker Kwaro was the 'cultural institution' of the Acholi. It was banned under the Obote administration but reinstated in the 1995 Constitution. It has an ambiguous role as, prior to 1995, there was no paramount chieftaincy or its equivalent.

${ }^{37}$ In her field research in Gulu in 2010 and 2011, Vorhölter noted the proliferation of community organizations focused on traditional justice and cultural revival when international funding for these activities became available (Vorhölter 2014: 165).
} 
not always know the clan of the child's father. Without this knowledge, they cannot claim land from the child's father's clan, as would usually occur, and they have difficulty claiming land from their own natal lineage. CBW limit their mother's property claims and such children will also have difficulty making property claims of their own.

Yet, children are not always the victims in post-conflict northern Uganda. Indeed, the social and economic upheaval caused by the conflict coincided with changes in the legal environment and undermined the customary institutions in a way that has given young people agency to choose customary or formal rights to land. Older adults complain of the actions of children raised in the camps or kidnapped by the LRA. They report that these adult children claim land from their clan and then sell it, thereby moving the land into the market and forever out of the possession of the clan. With the rapid rise in the population in northern Uganda and the large percentage of the population under fifteen, this is a serious concern. Young people are also blamed for creating conflicts around land and participating in violence related to land conflicts. As an institutional environment does not exist in which these land conflicts can be solved authoritatively, the intergenerational conflict over land will probably persist. Moreover, youth agency in accelerating the transition to formalized land tenure is unlikely to sit well with those who see the benefits of the former system.

Northern Uganda has much to show us regarding the interplay of forced migration, customary law and population change. Resource conflict there - and specifically access to land - has taken on an intergenerational quality as young adults take advantage of the growing market in land and eroded social institutions to sell clan land. The nature of children's rights under customary law can both make them vulnerable to the expropriation of their future land rights during crises and enable them to undermine the holdings of their clans should they have a choice between customary and statute law. With significant population growth, there are more young people with a claim on customary land and more youth are able to make this controversial choice.

Northern Uganda's cities are thriving and economic opportunities abound. The social institutions governing land access are contested and the mechanisms available to address resource conflicts have become venues for authority claims, rather than conclusively resolving disputes. In the wake of this social upheaval, there is a contestation of traditional structures of authority and resource access. But the transition is not yet over: full implementation of the Land Act and National Land Policy will further change the landscape of authority by creating the possibility for new venues of conflict resolution, and, eventually, local elections will add a new cohort of leaders with authority imbued by the state.

What we see in northern Uganda is instructive at a time in which many countries are creating mechanisms for the formalization of customary tenure institutions. What might be a slow process of institutional change is accelerated in post-conflict regions with population displacement. There are other parts of sub-Saharan Africa with similar circumstances of conflict, forced migration, rising land values and customary law. The north-east of Nigeria, where Boko Haram has been active, South Sudan and the Eastern Democratic Republic of Congo may anticipate similar types of problems when conflict ends and people return home. 


\section{Acknowledgements}

My thanks go to Mirriam Lakote for extremely helpful research assistance in Gulu. Ron Atkinson, Luka Klimacivuite, Mary Baganizi, Kilara Oruni, Annika Sampedro and Carol Summers all provided helpful input at some stage. I am also grateful for the contributions of two anonymous reviewers.

\section{References}

Adelman, S. and A. Peterman (2014) 'Resettlement and gender dimensions of land rights in post-conflict northern Uganda', World Development 64: 583-96.

Atkinson, R. R. (2010) 'Afterword: a perspective on the last thirty years' in The Roots of Ethnicity: origins of the Acholi of Uganda before 1800. Kampala: Fountain Publishers.

Boyden, J. (2003) 'Children under fire: challenging assumptions about children's resilience', Children, Youth and Environments 13 (1): 1-29.

Branch, A. (2011) Displacing Human Rights: war and intervention in northern Uganda. New York NY: Oxford University Press.

Dancer, H. (2015) Women, Land and Justice in Tanzania. Rochester NY: James Currey.

Deng, F. M. (2011) 'Customary law in the cross fire of Sudan's war of identities' in D. Isser (ed.), Customary Justice and the Rule of Law in War-torn Societies. Washington DC: United States Institute of Peace.

Dolan, C. (2009) Social Torture: the case of northern Uganda, 1986-2006. New York NY: Berghahn Books.

Drimie, S. (2002) 'The impact of HIV/AIDS on land: case studies from Kenya, Lesotho and South Africa' in A Synthesis Report Prepared for the Southern African Regional Office of the Food and Agricultural Organization of the United Nations (FAO). Pretoria: Integrated Rural and Regional Development, Human Sciences Research Council.

Girling, F. K. (1960) The Acholi of Uganda. London: Her Majesty's Stationery Office.

Hakansson, N. T. (1994) 'The detachability of women: gender and kinship in processes of socioeconomic change among the Gusii of Kenya', American Ethnologist 21 (3): 516-38.

Hampshire, K., G. Porter, K. Kilpatrick, P. Kyei, M. Adjaloo and G. Oppong (2008) 'Liminal spaces: changing inter-generational relations among longterm Liberian refugees in Ghana', Human Organization 67 (1): 25-36.

Hinz, M. O. (2010) Customary Law Ascertained: the customary law of the Owambo, Kavango and Caprivi communities of Namibia. Vol. 1. Windhoek: Namibia Scientific Society in association with the Human Rights and Documentation Centre.

Hopwood, J. and R. Atkinson (2013) 'The land conflict monitoring and mapping tool for the Acholi sub-region'. Gulu: United Nations Peacebuilding Programme in Uganda and Human Rights Focus.

Joireman, S. F. (2007) 'Enforcing new property rights in sub-Saharan Africa: the Ugandan constitution and the 1998 Land Act', Comparative Politics 39 (July): 463-80. 
Joireman, S. F. (2008) 'The mystery of capital formation in sub-Saharan Africa: women, property rights and customary law', World Development 36 (7): 1233-46.

Joireman, S. F. (2011) Where There is No Government: enforcing property rights in common law Africa. New York NY: Oxford University Press.

Joireman, S. F. (2014) 'Rebuilding communities after violent conflict: informal justice systems and resource access', Harvard Human Rights Journal (online symposium).

Joireman, S. F., A. Sawyer and J. Wilhoit (2012) 'A different way home: resettlement patterns in northern Uganda', Political Geography 31 (4): 197-204.

Kandel, M. (2016) 'Struggling over land in post-conflict Uganda', African Affairs 115 (459): 274-95.

Ker Kwaro Acholi (2008) 'Principles and practices of customary tenure in Acholiland'. Gulu: Ker Kwaro Acholi.

Kumam Elders' Forum (2011) 'Kumam principles, practices, rights and responsibilities (PPRR) for customary land tenure management'. Kampala and Soroti: Land and Equality Movement in Uganda.

McCallin, B. and M. Montemurro (2009) 'Whose land is this? Land disputes and forced displacement in the western forest area of Côte d'Ivoire'. Geneva: Internal Displacement Monitoring Centre.

Ministry of Lands, Housing and Urban Development (2013) 'The Uganda National Land Policy'. Kampala: Government of Uganda.

Nannyonjo, J. (2005) 'Conflicts, poverty and human development in northern Uganda'. WIDER working paper. New York NY: United Nations World Institute for Development Economics Research.

North, D. C. (1990) Institutions, Institutional Change and Economic Performance. New York NY: Cambridge University Press.

Obol-Ochola, J. (1973) 'The pilot scheme for the registration of titles in Kigezi', Uganda Law Focus 1 (3): 133-45.

Onegi, L. (2012) 'Post-conflict land insecurity threatens re-displacement in northern Uganda', Forced Migration Review 41 (December): 31-2.

Opiyo, L. M. (2015) 'Alone like a tree: reintegration challenges facing children born of war and their mothers in northern Uganda'. JRP situational brief. Gulu: Justice and Reconciliation Project.

Owot, P. (1976) 'Padibe during the Aconya: 1400-1900' in J. M. Onyango-kuOdongo and J. B. Webster (eds), The Central Lwo during the Aconya. Nairobi: East African Literature Bureau.

Pham, P., P. Vinck, M. Wierda, E. Stover and A. di Giovanni (2005) Forgotten Voices: a population-based survey of attitudes about peace and justice in northern Uganda. New York NY: International Center for Transitional Justice and the Human Rights Center, University of California, Berkeley.

Rincon, J. M. (2010) 'Ex-combatants, returnees, land and conflict in Liberia'. Copenhagen: Danish Institute for International Studies.

Roberts, B., K. F. Ocaka, J. Browne, T. Oyok and E. Sondorp (2008) 'Factors associated with post-traumatic stress disorder and depression amongst internally displaced persons in northern Uganda', BMC Psychiatry 8: 1-9.

Rose, L. L. (2005) 'Orphans' land rights in post-war Rwanda: the problem of guardianship', Development and Change 36 (5): 911-36.

Toulmin, C., P. L. Delville and S. Traore (2002) The Dynamics of Resource Tenure in West Africa. Portsmouth NH: Heinemann. 
Uganda Bureau of Statistics (2009) Statistical Abstract. Kampala: Government of Uganda.

Uganda Ministry of Health and World Health Organization (2005) 'Health and mortality survey among internally displaced persons in Gulu, Kitgum and Pader districts, northern Uganda'. Kampala: World Health Organization.

UNHCR (2015) 'Worldwide displacement hits all-time high as war and persecution increase'. Geneva: United Nations High Commissioner for Refugees (UNHCR).

van Leeuwen, M. (2014) 'Renegotiating customary tenure reform: land governance reform and tenure security in Uganda', Land Use Policy 39: 292-300.

Vorhölter, J. (2014) Youth at the Crossroads: discourses on socio-cultural change in post-war northern Uganda. Göttingen: Göttingen University Press.

Whyte, S. R., S. M. Babiiha, R. Mukyala and L. Meinert (2012) 'Remaining internally displaced: missing links to security in northern Uganda', Journal of Refugee Studies 26 (2): 283-301.

Woodman, G. (2008) 'A survey of customary laws in Africa in search of lessons for the future' in Customary Law Revisited. Gaborone: Leitner Center for International Law and Justice.

Woodman, G. R. (2011) 'A survey of customary laws in Africa in search of lessons for the future' in J. Fenrich, P. Galizzi and T. E. Higgins (eds), The Future of African Customary Law. New York NY: Cambridge University Press.

\begin{abstract}
Northern Uganda is in transition after the conflict that ended in 2006. While its cities are thriving and economic opportunities abound, the social institutions governing land access are contested, the land administration system is changing, and the mechanisms available to address conflicts over resources have themselves become a venue for authority claims. This article examines the intergenerational nature of land conflicts in northern Uganda, focusing on the interplay of customary law, return migration and the development of a market in land. There are three contributions to existing literature: (1) a discussion of children's property rights under customary and statute law in Uganda; (2) the identification of the dual nature of children during complex emergencies as both victims and agents; and (3) an addition to knowledge on post-conflict return and community reconstruction. Evidence comes from several sources, the most important of which are a set of interviews conducted in Gulu and Kampala in May and June 2015. Secondary sources augment the field research, particularly survey research conducted in northern Uganda after the conflict.
\end{abstract}

\title{
Résumé
}

Le Nord de l'Ouganda est en transition après la période de conflit qui s'est achevée en 2006. Les villes sont en plein essor et les opportunités économiques abondent, mais les institutions sociales qui régissent l'accès à la terre sont contestées, le système d'administration des terres est en mutation et les mécanismes disponibles pour pallier les conflits liés aux ressources sont euxmêmes devenus un espace de revendication d'autorité. Cet article examine la nature intergénérationnelle des conflits de terres dans le Nord de l'Ouganda, en s'intéressant à l'interaction du droit coutumier, de la migration de retour et du 
développement d'un marché foncier. Il y a trois contributions à la littérature existante : (1) une discussion des droits fonciers des enfants en vertu du droit coutumier et législatif en Ouganda ; (2) l'identification de la double nature des enfants dans les urgences complexes en tant que victimes et en tant qu'agents ; et (3) un complément à la connaissance sur le retour et la reconstruction communautaire après un conflit. Les données viennent de plusieurs sources dont la plus importante est une série d'entretiens menés à Gulu et à Kampala en mai et juin 2015. Les sources secondaires renforcent la recherche de terrain, notamment la recherche par enquête effectuée dans le Nord de l'Ouganda après le conflit. 